\title{
THE GENERA FLAMMULA AND PAXILLUS AND THE STATUS OF THE AMERICAN SPECIES ${ }^{1}$
}

\author{
C. H. Kauffman
}

(Received for publication February 13, I925)

Flammula (Fr.) Quél.

The Agarics of the ocher-spored group have had my attention during many years. During this period, I have from time to time put on record such data as I was able to gather concerning the occurrence and distribution of the American species of Cortinarius (I I) and Inocybe (I3). But field studies were continuously made also of the other genera of the group. However, it became increasingly difficult to identify with any feeling of certainty the collections of the genus Flammula that were picked up. During recent years, especially since the appearance of Murrill's (I4) compilation of the descriptions of American species, special attention was directed to this genus. It soon became evident that the genus Flammula was being used as a dumping-ground for species that did not seem to fit elsewhere-in other words, the generic limitations of this genus were no longer respected.

It will be necessary then to review the conceptions of the genus held by those who first limited the group and gave it scientific standing. Persoon (I8), as well as others of those early days, scattered such species as we can still roughly recognize among several sections of the old genus Agaricus. Fries (5), under his tribe XXV, gives the word "Flammula" its first characterization as follows:

Veil marginal, fibrillose, very fugacious, not glutinous. Stipe at first stuffed, then for the most part hollow, not bulbous, firm, fibrillose (not appressed-scaly from a transversely ruptured veil) homogeneous with the pileus. Pileus fleshy, convex-expanded, not striate, glabrous (very rarely with superficial scales and these not innate), dry or viscid. Flesh not thick, but firm. Gills not emarginate, variable.

In the Monographia (6), which is far and away the most carefully done and most useful of any of the works of Fries dealing with Agarics, we find the tribe "Flammula" distinguished as follows ( $1: 348)$ :

The Flammulae are distinguished among the ocher-spored Agarics by the fleshy-fibrous stipe, by the filamentous or obliterated veil, by the fleshy pileus, and by the acute, adnate or decurrent lamellae.

He adds further:

With reference to their natural affinity, it is clear from their bright-colored spores that they are nearest to the Pholiotae; from the Hebelomata and Inocybes they are far removed by their very nature. They form a natural group, although they represent four quite distinct types and the species of the first section differ so much from each other that one

${ }^{1}$ Papers from the Department of Botany of the University of Michigan, no. 224. 
could consider each single one as a type peculiar to itself. In most of the species the spores are pure ferruginous, but in $A$. carbonarius [ = Flammula] they are fusco-ferruginous, and in $A$. sapineus and its relatives they are fulvo-ochraceous. Some species are terrestrial, some lignicolous, and some thrive in either situation; for the most part they occur late in the season. In most the taste is insipid or bitter and they are therefore not edible.

In Hymenomycetes Europaei (7, p. 244), we find the same conception of the generic limitations as that just quoted, except for the addition of the emphatic statement that "the margin of the pileus is at first involute."

The other mycologists of the period covered by Fries' writings, as well as most of those who have since written Agaric manuals, have kept close to the meaning of the genus as defined in the quotation from Monographia. For example, Quélet (I9), who officially raised the group to the rank of a genus, merely by writing "genre" before the word Flammula, characterizes it thus: "Stipe charnu, lamelles adnées ou décurrentes," and places it between Hebeloma and Naucoria. Saccardo (22) cited the Systema of Fries, but copied the generic description from Hymenomycetes Europaei. Of recent works, in which the genus is kept intact, Ricken's Blätterpilze (2I) follows the Friesian conception and retains the species. Ricken places the genus between Pholiota and Naucoria, but remarks that the genus Hypholoma, except for its purple-brown spores, is very similar. Rea (20), breaking away from the traditional use of grouping the genera of similar spore color together, has placed the genus Flammula in his group of decurrent-gilled Agarics, along with Clitocybe, Hygrophorus, Clitopilus, and Gomphidius. This arrangement, with the phylogeny to be assumed as accompanying it, is of doubtful validity. It has already been criticized by Buller (3). The idea is not new. To quote W. G. Smith (23):

Fries says the natural affinity of Flammula is with Pholiota, but I consider all true Flammulas should correspond with Clitocybe and Clitopilus. I suspect some of the species of Flammula that approach Pholiota in structure might with propriety be removed to that subgenus and Flammula proper be restricted to species with decurrent gills.

There are, however, insurmountable difficulties in the use of the decurrent-gill character alone, since many species, with undoubtedly complete Flammula characters otherwise, have adnate gills. At the same time, Rea retains the fundamental Friesian characters of the genus, hoping to strengthen his position by limiting the adnate-gilled species to those with a decurrent tooth. To my mind, this can not be done without establishing other genera.

Turning now to other conceptions of the genus, we are met by the name Gymnopilus, proposed in 1879 by P. Karsten (9) for a portion of the old genus, and Gymnocybe for another portion. The former of these was selected by Murrill in his treatment of the genus in the North American Flora (14). The generic conception presented here is the same old Friesian conception. Quite a number of the species, however, which Murrill included, do not submit to the requirements laid down in his own generic description. These, as will be seen in the section of the present paper dealing with excluded species, had to be removed. 
Fayod (4) divided the species among the genera "Flammula Fr.," "Flammopsis," and "Ryssospora gen. nov." His own knowledge of the species of this group was undoubtedly scanty, and little use can be made of his statements about them. Hennings (8) reversed the method used by the preceding authors and "lumped" a number of Friesian genera, including most of the species of Flammula, under the genus Naucoria.

As far as I can see, no changes have been made in the Friesian conception of the generic limitations since the appearance of Hymenomycetes Europaei. The first paragraph from Fries' Monographia quoted above is a clear-cut statement of the characters of this genus. The further character of the involute young margin of the pileus has not been, as a rule, noted by authors of American species, so that it must, of necessity, be neglected for the present. A number of the species are now known to be characterized by cystidia in the hymenium, a fact, as we shall see below, that is of considerable diagnostic importance. Where changes have been attempted, authors contented themselves with taking the old facts, mainly established by Fries, and devising different arrangements of them. It would have furthered our knowledge of the genus much more if their efforts had centered on the development and anatomy of the known European species.

Ricken (2I), following in the footsteps of Bresadola (I), grasped the importance of getting new facts as well as the need for the study of living plants, and his records of the spores and the cystidia are of inestimable value to the American student. Much still needs to be done along this line in Europe, but a good start has been made. In this connection, it is very much to be regretted that Rea (20) has not given us his own critical account of all the microscopic characters of the British plants of this genus. Some dozen British species are here excluded because of the lack of such data.

The outstanding surprise of my study of the types of the species described in America was the fact that about half of the valid species had distinctly recognizable cystidia in the hymenium. This reduces the difficulty of recognizing the species at once to a remarkable degree. The presence or absence of cystidia, their character, shape, and size, are quickly determinative, where synonyms are open to question, or where species are alike. I had long known, from my own studies in the field, that a considerable number of species must possess cystidia, but the omission of this character in so many of Peck's and Murrill's descriptions made me wary and uncertain.

It is further surprising that, with the exception of Ricken, the cystidia in this genus have been rarely mentioned. Even Patouillard (I6, I7), who paid special attention to the hymenial structure of most of the genera, makes no mention of them in this genus.

The spores of many species are too similar in size to be dependable, although some species are clearly to be kept separate on spore characters. Fayod (4) and others have attempted to emphasize the germ pores present 
in the spores of a number of species, and eventually this character may prove of some value in the study of the relationships of the species of Flammula.

Since most species of Flammula are lignicolous, it is of considerable interest to know to what extent their occurrence is limited by the nature of the wood on which they occur. Although saprophytes, we know that for many basidiomycetes a coniferous substratum on the one hand, and wood from frondose trees on the other, are frequently limiting factors. In so far as sufficiently reliable data are at hand, I have attempted to emphasize this feature in the following synopsis. Fries himself emphasized it. The "Sapineae," occurring on coniferous wood, are a natural group, not only in this respect but apparently also in the fact that these species lack cystidia and have a non-viscid pileus.

One hundred and five names, applied to species of Flammula, are referred to in this paper. About half of these have been placed in the excluded list. There remain fifty-two species with a more or less excellent claim to validity. These include those American and European species about which we have fairly definite information.

For the present, and until the American species are better known, it is futile to attempt any detailed discussion of relationships within the genus. The subdivisions made by Fries are at present convenient enough as receptacles for the added American species, and much collecting and careful microscopic work is necessary before the knowledge of our species is at all adequate. This paper has been prepared in the belief that it will establish an entirely new starting point for the study of American species of Flammula, and as many data as space permitted have been included to promote such a study.

I am under special obligation to the authorities of the New York Botanical Garden for permission to examine the types of Dr. Murrill's species; to Dr. House at Albany for free access to Dr. Peck's species; and to the Department of Plant Pathology of the New York State College of Agriculture for opportunity to study the collections of Flammulae in the Atkinson Herbarium.

Practically all American type specimens have been carefully gone over. A few could not be found or are no longer in existence. It is not likely that the number of American species is as great as in some of the related genera of the Ochrosporae, and great care should be exercised in describing new ones because of the close similarity of species from the related genera, such as Cortinarius, Pholiota, and Naucoria.

\section{Synopsis of the Species of Flammula of the North Temperate Zone}

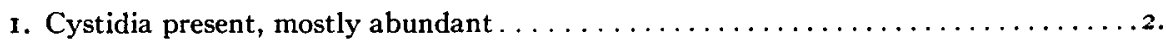

I. Cystidia lacking (frequently sterile cells occur on the edges of the gills; these may be

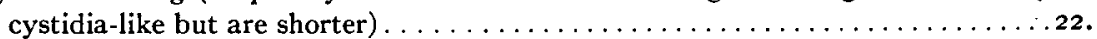

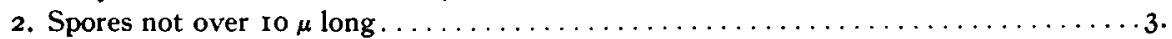


2. Spores I 2-I $6 \times 6-7 \mu$; odor and taste mild; pileus 3-5 $\mathrm{cm}$. broad; viscid, glabrous, isabelline or with brownish disk; gills broad, decurrent by lines; stem $5^{-8} \mathrm{~cm} . \times 7$ Io $\mathrm{mm}$.; in coniferous forests, on or near coniferous wood (Europe).

F. mixta Fr.-Ricken.

3. Pileus viscid, glutinous, or sub-viscid, pellicle separable $\ldots \ldots \ldots \ldots \ldots \ldots \ldots$.

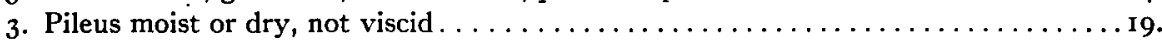

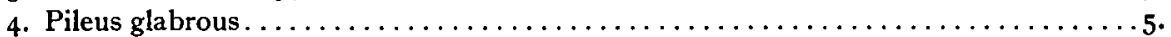

4. Pileus at first with superficial scales from the universal veil, at least on the margin. I 14.

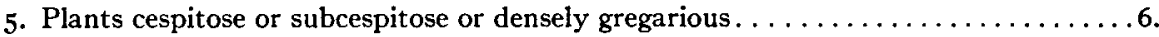

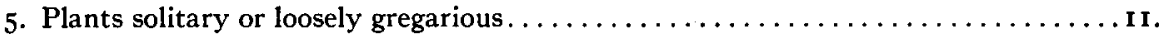

6. Spores $7-8.5$ or $7-10 \mu$ long; odor noticeable (except in $F$. fibrillosipes) $\ldots \ldots \ldots \ldots 7$.

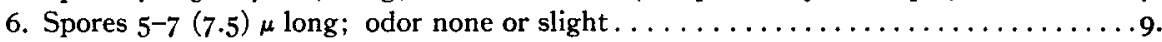

7. Odor penetrating, rather strong, especially when the plant is crushed or during

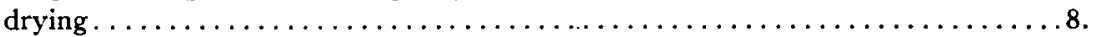

7. Odor none; taste subacrid; pileus reddish-brown, darker on disk, at first appendiculate on margin; stem densely fibrillose, solid; cortina copious, persistent; spores 7-8.5 X 3.5-4.5 $\mu$; cystidia few to scattered (Alabama)..........F. fibrillosipes Murrill.

8. Spores 7.5-Io $\times 4.5^{-6} \mu$; gills broad and almost subdistant, at first yellowish; pileus brownish-yellow, umbo darker; densely cespitose, cystidia rather abundant; on pine wood or clearings in pine wood..................... condensa $\mathrm{Pk}$.

8. Spores $6-8(8.5) \times 4-4.5 \mu$; gills medium broad, close; pileus yellow or yellowish with tawny centre, obtuse pellicle subseparable or adnate; flesh of pileus and stem pale yellow; cystidia abundant; cortina evanescent; on or about coniferous wood.

F. graveolens $\mathrm{Pk}$.

9. Stem slender, $2-4 \mathrm{~mm}$. thick; pileus $2-4(5) \mathrm{cm}$. broad; gills at first pallid . . ... ro.

9. Stem 3-8 (ro) mm. thick, 3-7 cm. long, fibrillose, stuffed-hollow; pileus $2-5 \mathrm{~cm}$. broad, yellow shades predominating, disk darker; margin of pileus, young gills and flesh of pileus citrine-yellow; cortina evident, citrine; gills adnate, decurrent by tooth; in coniferous and frondose (?) woods. Spores $5-6.5(7) \times 3.5^{-4} \mu$ (Europe and America).

F. spumosa Fr.-Ricken.

F. subflavida Murrill.

F. piceina Murrill.

I0. Growing on charred wood or burnt-over ground, densely gregarious or subcespitose; gills rather broad, close to crowded; pileus brownish-incarnate to dull reddish-brown; spores $6-7 \times 3-4 \mu$ (Europe and America).

F. carbonaria Fr. (sense of Ricken, Patouillard, and Rea).

10. Growing in swampy woods, especially under alders, cespitose; gills adnate; stem subcartilaginous; pileus sordid yellowish-rufescent; spores 6-7 $\times 4-4.5 \mu$. F. squalida $\mathrm{Pk}$.

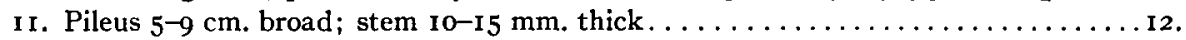

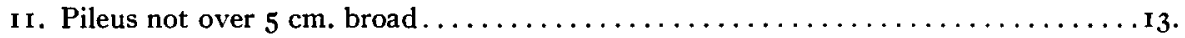

12. Gills near maturity rusty, tinged with gray-olivaceous; stem rooting-attenuate, fibrillose-streaked, concolor; pileus subtestaceous; spores $8-9 \times 4-5 \mu$; on and about

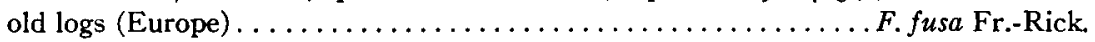

I2. Gills cinnamon-fulvous at maturity; stem equal or incrassate below, whitish, with yellow mycelium at base; pileus rusty-fulvous, pallid on margin; spores 6-7 $\times 3.5^{-}$ $4 \mu$; on $\log$ of frondose tree (western United States) ...........F. lata Murrill.

I3. Hymenium with metalloid cysts; pileus $2-3.5 \mathrm{~cm}$. broad, yellowish-red; stem hollow, minutely floccose-scaly; spores 6-8 $\times 4-4.5(5) \mu$; cystidia subabundant, scattered or few, on and near edges of gills; on burnt ground in the open, or on débris in woods (F. ascophora $\mathrm{Pk} . ; F$. pusilla $\mathrm{Pk}$.)................... highlandensis $\mathrm{Pk}$.

I3. Hymenium without such cysts; pileus $3-5 \mathrm{~cm}$. broad, bay color or with yellow tints; gills broad, at first citrine; stem fibrillose, equal, I0-15 mm. thick; spores $6.5-7.5$ 
x 3.5-4 $\mu$; cystidia scattered, on and near edges of gills; on a railroad tie (western United States) . ...................................

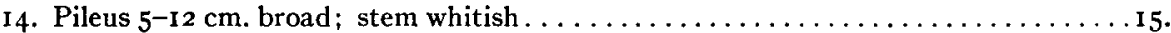

14. Pileus up to $6 \mathrm{~cm}$, rarely $7 \mathrm{~cm}$. broad . . . . . . . . . . . .

15. Pileus "zinc-orange" (Ridg.), darker or tawny-fulvous on disk, glutinous, stem loosely fibrillose; spores $5-7 \times 3-4 \mu$; on or about decayed logs, débris, etc. (Europe and America) ..................................... lubrica Fr.

15. Pileus pale buff to grayish, glutinous, viscid, or subviscid; gills adnate-subdecurrent or with tooth; cystidia abundant, $50 \times 12-14 \mu$, stout.

(a) Pileus 5-12 cm. broad; on white birch; spores 6-7 $\times 4^{-5} \mu$, subreniform.

F. betulina $\mathrm{Pk}$.

(b) Pileus 2-7 cm. broad; on much decayed wood débris or leaf mold; spores $5^{-6.5} \times 3^{-}$

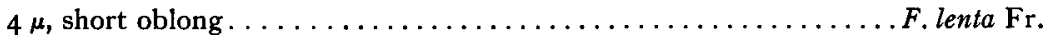

16. Plants more or less cespitose; spores $6-7.5 \times 3.5-4 \mu \ldots \ldots \ldots \ldots \ldots \ldots \ldots 17$.

I6. Plants solitary or scattered on sticks and fallen branches; spores $5-6.5 \times 3-4 \mu$; pileus yellowish to dull orange on disk, greenish-olivaceous on margin, decorated with creamy scales, $3-7 \mathrm{~cm}$. broad; gills at length olivaceous-purplish-gray, adnate or spuriously subdecurrent; stem slender, $3-5 \mathrm{~mm}$. thick, scaly; on sticks or fallen branches (eastern United States) ..................... polychroa Berk.

17. Pileus pale cream-color or pale ochraceous, with olive hues, flesh whitish. (See also

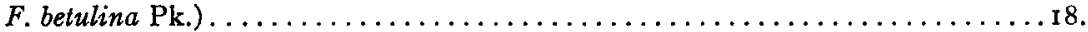

17. Pileus sordid-tawny, unicolorous, darker appressed scales on margin; flesh grayishwhite; cystidia lanceolate, $60-75 \mu$ long, slender with wavy outlines; about the bases of trunks, etc.................................... subfulva $\mathrm{Pk}$.

I8. Stem slender, 3-6 mm. thick, creamy-white, fibrillose-scaly; scales on disk or umbo of pileus "bay" (Ridg.) or chestnut; cystidia very abundant, 60-75 $\mu$ long; on fallen branches (Western United States) . . . . . . . . . . . . . . F. decorata Murrill.

I8. Stem 4-Io mm. thick, base rusty-reddish when bruised; scales of pileus evanescent; cystidia scattered, $45^{-50} \mu$ long; about the bases of trunks and stumps (Europe and

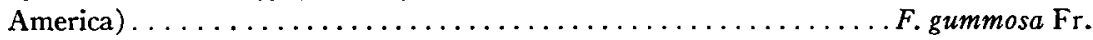

19. Pileus $5^{-10} \mathrm{~cm}$. broad; stem $7-10 \mathrm{~mm}$. thick, densely cespitose $\ldots \ldots \ldots \ldots \ldots 20$.

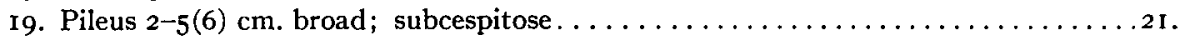

20. Spores $6-7 \times 3-4 \mu$; cystidia $60-75 \times$ I2-I $7 \mu$; pileus not viscid, straw-yellow with rusty-brown disk, margin with shreds of veil; gills broad; odor penetrating, strong; taste bitter; on stumps (Europe and America!) ( $F$. alnicola Ricken)

F. amara Bull.-Ricken.

20. Spores 8-9 $\times 4-5 \mu$; cystidia $36-40 \times 8-9 \mu$; pileus not viscid, sulfur-yellow, at first with pale appressed scales on surface or margin; gills rather narrow; odor none or earthy; on and about trunks (Europe and America).........F. flavida Fr.-Ricken.

21. Pileus hygrophanous, dark umber when moist, fading; gills subdistant to distant; stem tough, $4^{-6} \mathrm{~cm}$. long, $4^{-6} \mathrm{~mm}$. thick; spores $7^{-9} \times 4^{-5 \mu}$; on rotten logs (Alabama) .................................... unicolor Murrill.

2I. Pileus not hygrophanous, sulfur-yellow, disk reddish-orange; cortina copious; stem 2-5 cm. long, 2-4 mm. thick; cystidia abundant, with wavy outline; spores $6.5 \times 4-$ $5 \mu$ (western United States) . . . . . . . . . . . . . . . . . .

22. Growing on wood of coniferous trees, logs, stumps, decayed remnants, etc.; pileus dry

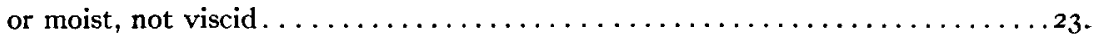

22. Growing on wood of frondose trees, rarely on the ground; pileus viscid, subviscid, or

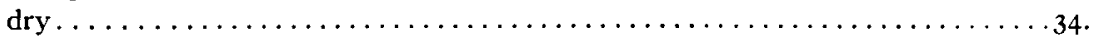

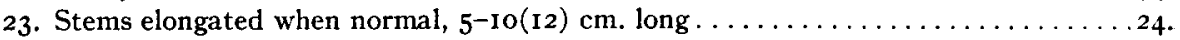

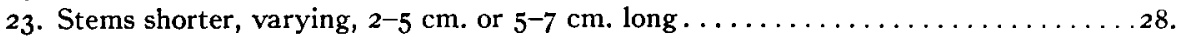

24. Stems slender, $2-5$ mm. thick; pileus glabrous; plants subcespitose . . . . . . . 25.

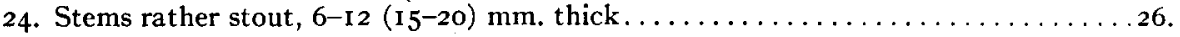


25. Pileus red-orange-incarnate, deeper color on disk, $3-5(7) \mathrm{cm}$. broad, margin whitishsilky; stem stuffed-hollow, fibrillose to subscaly; taste bitterish; spores 6-7 $\times 3$ $3.5 \mu$ (Europe and America) . . . . . . . . .

25. Pileus alutaceous-honey color, $4-8$ (Io) $\mathrm{cm}$. broad; cortina very evanescent; stem fistulose, pallid, at length testaceous or fuscescent, appressed-fibrillose; gills narrow, at length grayish-olivaceous; spores $6-7.5(8) \times 4-4.5 \mu$ (Kauff.) sordid rusty (Europe and America $\ldots \ldots \ldots \ldots \ldots \ldots \ldots \ldots \ldots \ldots \ldots \ldots \ldots \ldots \ldots \ldots \ldots \ldots$ inopoda Fr.

26. Pileus some shade of yellow; plants cespitose $\ldots \ldots \ldots \ldots \ldots \ldots \ldots \ldots \ldots \ldots \ldots 27$.

26. Pileus dull green, 4-8(ro) $\mathrm{cm}$. broad; stem and pileus at first with pulverulent bluishgreen bloom; gills greenish; taste bitter; spores $5-7 \times 3.5-4 \mu$ (western United States $\ldots \ldots \ldots \ldots \ldots \ldots \ldots \ldots \ldots \ldots \ldots \ldots \ldots \ldots \ldots \ldots \ldots \ldots \ldots$ subvidis Murrill.

27. Pileus 10-I5 cm. broad, pale yellow, deeper-colored in age, subfibrillose; stem 7-10

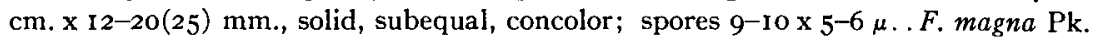

27. Pileus 4-10 $\mathrm{cm}$. broad, yellowish-brown, minutely scaly; stem radicating, streaked;

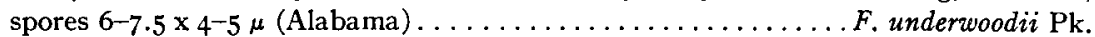

28. Pileus more or less floccose-scaly with small scales, or floccose-granulose . . . . . . 29.

28. Pileus glabrous; plants subcespitose; base of stem white-villose; gills yellow or golden,

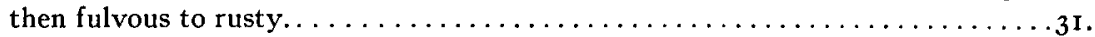

29. Stem $3-8 \mathrm{~mm}$. thick. . . . . .

29. Stem slender, Naucoria-like, 2-3 mm., lacerate-subscaly; pileus $3-5 \mathrm{~cm}$., rusty-fulvous; spores $6-7 \times 3^{-4} \mu$ (Schroeter) (Europe) . . . . . . . . . . . . F. limulata Fr.

30. Pileus slightly viscid when moist, soon dry, more or less yellow, with pink or purplish shades especially on disk, $2.5-5 \mathrm{~cm}$. broad; gills broadly adnate, becoming bright tawny-ochraceous, spores 6-7.5(8) x 4-5 $\mu$ (syn. F. pulchrifolia $\mathrm{Pk}$.) . F. braendlei Pk.

30. Pileus always dry, golden-fulvous, tawny or rusty yellow, of ten difformed, $3-8 \mathrm{~cm}$. broad; stem persistently stuffed, equal, sometimes eccentric, fibrillose to subscaly; gills rather broad, adnate, becoming fulvous-cinnamon; spores $7-8(9) \times 4-5 \mu$ (Europe and America) (syn. F. eccentrica Pk.) ............... sapinea Fr.

31. Cortina none; flesh of pileus colored; stems slender $\ldots \ldots \ldots \ldots \ldots \ldots \ldots \ldots \ldots$.

3I. Cortina evanescent or copious; flesh of pileus white to pallid; stems rather stout,

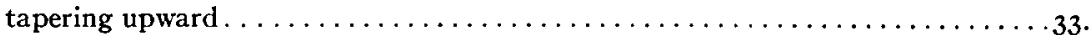

32. Stem umber-colored, at first everywhere covered by whitish pulverulence, fistulose, slender, 2-5 mm. thick; gills very narrow; pileus bay-brown, 2-4 cm. broad; spores $8-10 \times 5-6 \mu$ (Schroeter) (Europe) . . . . . . . . . . . . . . . F. picrea Fr.

32. Stem fulvous, then ferruginous, naked, 4-7 mm. thick; gills rather broad; pileus $3^{-8}$ $\mathrm{cm}$. broad, very glabrous, golden-yellow to orange-fulvous, spores $8-9 \times 4.5-5.5(6) \mu$ (Kauff.) (Europe and America) . . . . . . . . . . . . . . . liquiritiae Fr.

33. Gills becoming fulvous-spotted in age, at first whitish; pileus dry, yellow-fulvous, fading in age, $5-8 \mathrm{~cm}$. broad; spores subventricose, $6-7.5 \times 3.5-4.5 \mu$ (Europe and America) . . . . . . . . .

33. Gills not spotted in age, at first yellow; pileus moist, at first cinnamon-fulvous, becoming orange-fulvous, $5-8 \mathrm{~cm}$. broad; stem white-cortinate; spores $7-9$ (I0) $\times 4-5(6) \mu$

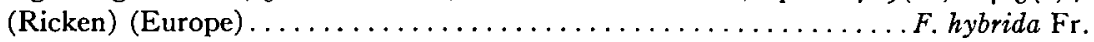

34. Pileus viscid or with subviscid pellicle, glabrous or subfibrillose $\ldots \ldots \ldots \ldots \ldots \ldots$.

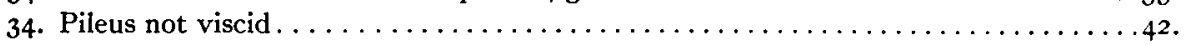

35. Spores not with rufous tints, usually smaller, ellipsoid $\ldots \ldots \ldots \ldots \ldots \ldots \ldots \ldots$.

35. Spores in mass "cinnamon-rufous" (Ridg.), 9-I $2 \times 4-5(5.5) \mu$, fusiform; pileus soon dry, "apricot-yellow"; gills yellowish-cinnamon, then "sayal-brown"; stem rigid, 4-8 mm. thick, cespitose; base of trunks (Europe and America) . . . . . F. conissans Fr.

36. Stems slender, $3-7 \mathrm{~mm}$. thick . . . . . . .

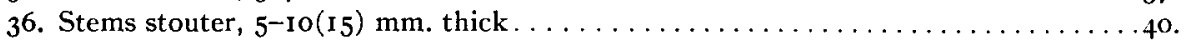

37. Plants cespitose to subcespitose . . . . . . . . . . . . . . . . . . . .

37. Plants solitary or few; pileus dark rich brown, $3-5 \mathrm{~cm}$. broad; flesh dark yellow; 
stem 4-5 cm. long, yellowish-brown; taste mild; spores $6.5^{-8.5} \times 3.5^{-4} \mu$; on the ground (!) in pine woods (Alabama) .................. castanea Murrill.

38. Pileus not hygrophanous nor sulfur-yellow (dry) $\ldots \ldots \ldots \ldots \ldots \ldots \ldots \ldots \ldots \ldots \ldots \ldots \ldots$.

38. Pileus hygrophanous, distinctly viscid, umbonate, watery-yellow (moist), sulfuryellow (dry), $2-6 \mathrm{~cm}$. broad; gills narrow, arcuate; spores 8-I0 $\times 4-5 \mu$; under apple trees $(F$. sulphurea $\mathrm{Pk}$. non Massee) ................. malicola nom. nov.

39. Pileus yellowish, disk fibrillose and tinged pale rose-brown, soon dry, 2-3 $\mathrm{cm}$. broad; stem glabrous above, shaggy-fibrillose below, sub-concolor; spores $5-6 \times 3.5 \mu$; roadside (western United States) .................... ornatula Murrill.

39. Pileus bright yellowish-brown, reddish-brown on disk, distinctly viscid; gills subdistant; stem whitish, hollow, subfibrillose, $5^{-6} \mathrm{~cm}$.long; spores $7-8 \times 3.5-4 \mu$; on clay banks! (Alabama) ................................... alabamensis Murrill.

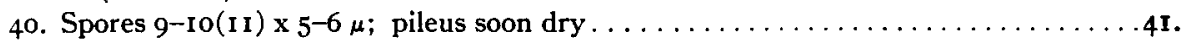

40. Spores $6-7 \times 3-4 \mu$; pileus pale ochraceous, mixed with buff and olive hues, sometimes cortinate-scaly on margin, glutinous; stem 4-6 cm. long, pallid above, at length reddish-umber below; about rotten logs or débris (Europe and America).

F. gummosa Fr.

4I. Pileus crust-like to alutaceous-fulvous, 5-10 cm. broad; gills broad; odor strong and bitter; gregarious by roadsides in mixed forests (Europe and America).

F. lupina Fr.-Ricken.

4I. Pileus isabelline, $5-7 \mathrm{~cm}$. broad; solitary in forests; gills subdistant, broad; on dead wood (western United States) ..................... permollis Murrill.

42. Pileus hygrophanous, small, not over $5 \mathrm{~cm}$. broad $\ldots \ldots \ldots \ldots \ldots \ldots \ldots \ldots \ldots \ldots \ldots \ldots$,

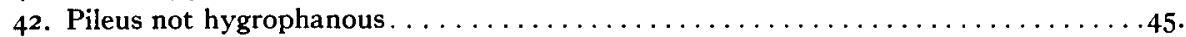

43. Gills narrow. .........................................

43. Gills broadly adnate, narrowed in front; pileus $2-4 \mathrm{~cm}$. broad, glabrous, subferruginous (moist), buff (dry); stem tough, concolor, 3-6 mm. thick; spores 7-8.5 $\times 4^{-5 \mu}$;

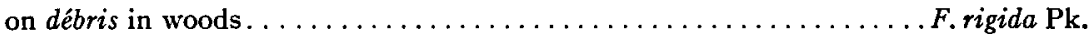

44. Growing in pastures; pileus subferruginous (moist), yellowish (dry), glabrous, $2-5 \mathrm{~cm}$. broad; stem equal, hollow, reddish-brown; spores 7.5-I0(I I ) x 5-6 $\mu$; "in pastures."

F. halliana $\mathrm{Pk}$.

44. Growing on trunks of apple trees or rotten wood; pileus ferruginous and glabrous (moist), alutaceous and rimose-scaly (dry), 2-4 cm. broad; stem stuffed-hollow, 4-6 $\mathrm{mm}$. thick, pale rust-color; spores I0-I2(I4) x 5-7 $\mu$ (Europe).

F. azyma Fr.-Ricken.

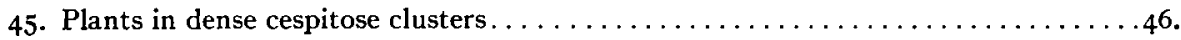

45. Plants single, gregarious, or subcespitose; gills crowded and narrow . . . .

46. Spores $7-9 \times 4^{-5} \mu$; pileus $4-8 \mathrm{~cm}$. broad, "apricot-yellow" (Ridg.), fibrillose-subscaly on margin; stem 6-10 cm. long, 3-8 mm. thick, densely fibrillose-cortinate; gills broad, at first pallid or tinged yellowish, then "ochraceous-tawny" (Ridg.); on Alnus, birch, etc., stumps and trunks (Europe and America) .......F. alnicola Fr.

46. Spores 5-6.5(7) x 3-3.5(4) (Rea \& Romell.); pileus 2.5-5 cm. broad, straw-color, becoming greenish, silky; stem $5-6 \mathrm{~cm}$. long $\times$ 4-1o $\mathrm{mm}$. thick, yellowish, whitefloccose and scaly; base becoming rusty-red; gills narrow and crowded, at first whitish, then olivaceous; on trunks and wood (Europe).......F. ochrochlora Fr.

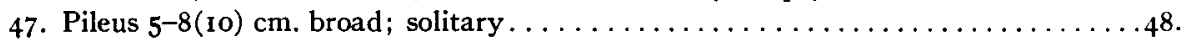

47. Pileus $2-5 \mathrm{~cm}$. broad, "antimony-yellow" to "ochraceous-buff" (Ridg.), glabrous; gills subdecurrent by tooth, soon "ochraceous-buff" to rusty; stem 2-5 cm. x 2-5 mm., flavescent; spores suboval, 7-8.5 $\times 4-5 \mu$; odor penetrating, taste bitterish; about stumps (eastern United States) ................ flavidella Murrill.

48. Stem 2-4 cm. long, 4-6 mm. thick, yellow; gills yellow, changing to brown where wounded, edge beaded with drops; pileus subglabrous, tawny; spores oval, 6-7.5

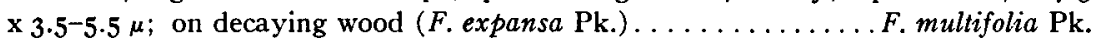


48. Stem $10-12 \mathrm{~cm}$. long, 8-10 mm. thick, white, glabrous; gills pale cinnamon; pileus glabrous, pale yellowish-tan; spores $8-10.5 \times 5-6.5 \mu$; base of living maple tree (eastern United States) ........................ ludoviciana Murrill.

\section{Comments on Selected Species of Flammula}

Since certain species have a distinctly bitter taste or a penetrating odor, these characteristics will be especially noted below.

Flammula alnicola Fr. At least two different species are masquerading under this name in Europe. One possesses cystidia, in the other cystidia are lacking. Ricken's plants under this name are something else, since neither his description, which includes cystidia, nor his figures agree with the account of Fries. Specimens, however, from Bresadola and Romell, now at the New York Botanical Garden, have all the ear marks of the genuine Friesian species. The latter have no cystidia. I have collected this species in the Adirondack Mountains. The pale lemon-yellow to apricot-colored pileus, the broad gills, and long cespitose stems are among the distinguishing characters; the stem is densely fibrillose in the growing condition, and the fibrils and the lower part of the stem darken in a characteristic manner to "raw sienna" or dull "ochraceous tawny" (Ridg.), which persists as a distinctive character in the herbarium specimens. The pileus is not viscid, although moist and slightly slippery to the touch, and its margin is fibrillose. The odor is somewhat aromatic, and the taste varies from mild to bitterish.

Ricken united Bulliard's species $F$. amara, with a bitter taste and a strong penetrating odor, with the Friesian species. It appears that we may have this plant in the United States also; at least I have met with plants which fit Ricken's species. It seemed desirable, therefore, to include $F$. amara in my synopsis.

Flammula astragalina Fr. I have collected this both in Sweden and in the mountains of Washington and Oregon. The western specimens are quite typical and also agree with Murrill's recently described $F$. laeticolor. The pileus is "bittersweet-orange" (Ridg.) in color, or "flame scarlet" on the disk. This red-colored cap is unique. Ricken describes cystidia, but neglects to say whether they occur on the sides of the gills in his plants. The Swedish plants have no cystidia, merely sterile cells on the gill edge. The taste is bitterish, odor none.

Flammula breandlei $\mathrm{Pk}$. There is no doubt in my mind that $F$. pulchrifolia $\mathrm{Pk}$. is identical. The principal issue remaining unsolved is the question of whether by any chance these two species are Pholiota aeruginosa Pk. In this connection I may say there is no question that some of the collections in the Peck herbarium under $F$. pulchrifolia belong to this Pholiota. The type specimens of both, however, do not look quite like dried $P$. aeruginosa. Overholts ( 15 ), who has recently redescribed this Pholiota, does not mention pink or purplish hues on the pileus, a coloring definitely given by Peck for his two Flammulae. The gills of the two forms are apparently also distinctive. In the Flammula they are markedly broad at the region of attach- 
ment. In the Pholiota the pileus is dry and becomes diffracted-scaly; in the Flammula it is said to be slightly viscid, although soon dry. In the Flammula the taste is said to be bitter and unpleasant. The spores are alike; cystidia are lacking in both; the gills at maturity become bright ochraceous-orange; and both occur on coniferous wood.

Flammula carbonaria Fr. This species seems to be widely distributed, but less common than ordinarily supposed. $F$. highlandensis is certainly closely related to it, both by its habit of sometimes growing on charred wood débris and by its cystidia and spores. However, $F$. highlandensis differs from $F$. carbonaria in its metalloid cysts, although the extent to which these may occur in other species is still an open question. I have observed a slight tendency to produce such cysts in an otherwise good $F$. carbonaria. $F$. highlandensis grows in other situations more frequently and is at times solitary. I have no genuine $F$. carbonaria collected in Michigan, but have collections from Maryland and North Carolina, the latter communicated by Professor Coker. The cystidia are typical Flammula cystidia, lanceolate, ventricose above the slender pedicel, and measure about 50-60 x 9-I4 $\mu$. The length given for them in the North American Flora must be considered an error. Odor none, but with a peculiar bitterish taste. (See remarks under $F$. highlandensis.)

Flammula condensa $\mathrm{Pk}$. I have this from the Medicine Bow Mountains of Wyoming, where it grew on logs of lodgepole pine. The type specimens came from pine woods in the District of Columbia. The gills are broadly adnate-subdecurrent. It differs from the "spumosa" group in the more variable and extreme size of its spores. The stem is at first yellowish, becoming "old gold" (Ridg.), at length sordid brownish-rusty downwards. It has a strong, pungent odor, which was naturally not sensed by Peck because he received his specimens from a distance.

Flammula conissans Fr. This is a well marked species not mentioned by Murrill or by Peck. It was collected twice by me near Professor F. C. Stewart's camp at Seventh Lake in the Adirondack Mountains. Both lots grew at or near the base of a yellow-birch trunk, one of them alive. The spore print is characteristic, "cinnamon-rufous" (Ridg.) against the yellow caps. On white paper a thin layer is more brownish; a thick layer more reddish. The size and shape of the spores are also distinctive; they are subfusiform and measure $9-\mathrm{I} 2 \times 4-5(5 \cdot 5) \mu$. Fries says the odor is acid; Ricken, that it has no odor. The plants collected by me had a subspicy odor.

Flammula decorata Murrill. This is also a well marked species which I have collected in Oregon on the fallen branches of some hardwood. The size of the cystidia is not correctly given by Murrill, as shown by an examination of the type specimens with which my collections agree. They are abundant, lanceolate, tapering upward from the widest portion, with short pedicel, hyaline, thin-walled, and measure $65^{-75} \times$ IO-I5 $\mu$. This species 
belongs to the fuscous-spored group. The taste is slowly bitter and somewhat nauseous. It has no special odor.

Flammula flavida. This species, although considered by Peck to occur in the United States, is not yet definitely placed among our species. Murrill (I4) omits it, and I have no specimens which I am able to place in it. According to European accounts, it is one of the larger Flammulae.

Flammula flavidella Murrill. The plants are about the size of Naucoria geminella Pk., which Murrill (14, p. 200) has transferred to Flammula; in my judgment this species is clearly a Naucoria, differing from $F$. flavidella by its slender cartilaginous stems, the emarginate gills, and a more scattered habit of growth. The spore sizes of $N$. geminella and of $F$. flavidella are the same. This Flammula has been collected around Ann Arbor. The pileus is "antimony-yellow" to "ochraceous buff"; the stems are stuffed, then hollow, fleshy-fibrillose, pruinose at apex, subglabrous elsewhere; the odor is rather penetrating, specific; the taste is distinctly bitter. The plants were quite cespitose and were growing on rotten logs. There are no cystidia present, but the edges of the gills are provided with slender, cylindrical sterile cells. The spores of the type specimens are obscurely echinulate, broadly elliptical to suboval, $7-8(8.5) \times 4-5 \mu$, slightly smaller than given by Murrill.

Flammula graveolens $\mathrm{Pk}$. This species, like $F$. condensa, differs from the "spumosa" group in its somewhat larger spores. It is to be considered a segregate of $F$. spumosa. It has the strong, penetrating odor of $F$. condensa, but differs from this species in its smaller, less variable spore size, generally larger pileus, and stouter stems. In $F$. condensa the gills are broad and subdistant; whether they are closer and narrower in $F$. graveolens is not clear. The cystidia of the type specimens of these two species are alike. Except for the difference in spore size, the other differential characters might very well vary to the extent given in the descriptions of the two. It seems to occur much more frequently than $F$. spumosa.

Flammula gummosa Fr.-Ricken. This species occurs in frondose woods, on decayed wood and débris. Its microscopic characters are at once different from the usual cystidia-bearing Flammulas. The basidia are 22$25 \mu$ long, 4-spored, and the short cystidia scarcely project above them, varying in length from $30-50 \mu$, somewhat ellipsoid or ellipsoid-acuminate in shape. Besides the spore-bearing basidia and cystidia, one finds the usual basidium-like sterile elements of the hymenium - the "paraphyses" of Buller (2). A few other species with similar unaccentuated cystidia have been placed among the cystidia-bearing group in my synopsis. The viscid pileus may or may not retain the spot-like scales. The flesh is scissile, indicating its hygrophanous character. The edges of the gills are floccosecrenulate. The taste and odor is slight or none. [See further Kauffman (II) and Ricken (2I)].

Flammula halliana Pk. There is a colored drawing of Peck's with the 
type material. At the first view of this, one is reminded of Cortinarius sphaerosporus $\mathrm{Pk}$. It is, however, not at all that species, but the impression remains that this species is a better Cortinarius, especially because of the hygrophanous pileus, which is said to be substriate on the margin when moist. Its decurrent gills are the main objection to placing it in that genus, although some good Cortinarii have a tendency towards decurrent gills. The gills and the dry pileus are pale yellowish buff. The spores are roughish, broadly elliptical, and rusty brownish-ochraceous, $7.5^{-} \mathrm{IO}(\mathrm{II}) \times 5^{-}$ $6 \mu$ in size. There are no cystidia.

Flammula highlandensis $\mathrm{Pk} ., F$. ascophora $\mathrm{Pk}$., and $F$. pusilla $\mathrm{Pk}$. are to be considered identical from their general characters and from the unique bodies which are borne in the hymenium. These are well illustrated by the figure given by Dr. Peck (New York State Museum Report 24, Pl. 3, fig. 5), and remind one of certain metalloid bodies in the hymenium of other basidiomycetes. They are sac-like with granular or blocked-out content, projecting very slightly above the basidia except when fully developed, apparently with a rather narrow pedicel below. Peck thought that ascospores were produced within these bodies and that these were the normal spores of this plant. Later he recognized his error and considered it a form of $F$. highlandensis (N. Y. State Mus. Rep. 50: I39). He did not, however, as far as I know, find the same bodies in the type of $F$. highlandensis. Although less prominent in the latter material, probably because of the younger age of the plants I examined, they can nevertheless be made out as a definite character of this species. Further, they are also present in the hymenium of the type plants of $F$. pusilla. This uniformity of occurrence is not likely explainable on the supposition that a parasitic fungus is present in the gills of this species. I believe them to be a normal development belonging to the life history of the species. Murrill (I4) refers here also Naucoria subvelosa Murrill and Hebeloma Peckii House, but I have not studied the types of these two. $F$. highlandensis occurs in Michigan. It was referred to (II, p. 488) as "F. carbonaria Fr. var." Cystidia of the normal type vary in number from few to fairly abundant, mostly near the edges of the gills.

Flammula inopoda Fr. What I feel quite confident is this species of Fries, I have from the Rocky Mountains in Colorado (Kauffman, 12). There is also a good example of it in the Atkinson Herbarium, from New Brunswick, Canada. It appears to have been unrecognized in this country, and is apparently rare. As shown in the figures of Fries (Icones, PI. I I8, fig. I), it has the habit of $F$. astragalinus, and like the latter occurs on coniferous wood. The stems of the American plants are rather long and slender, tapering downward to the point of attachment, and in age becoming fuscescent downward; the gills are "smoke-gray" to "light-grayish-olive" (Ridg.), tinged sordid olivaceous in age; the pileus is colored "warm buff" except on the deeper yellowish center, somewhat moist, not viscid; cystidia are lacking or are represented by scattered apiculate cysts; the spores 
measure 6-7.5(8) x 4-4.5 $\mu$, rusty-ochraceous under the microscope. Ricken (2I) considers Fries' species merely a variety of $F$. fusa. Rea (20) gives a description of it, but whence comes the tradition that its spores are "purple" he does not say. The spores of our plants are certainly not purplish, even though the gills possess gray shades.

Flammula lata Murrill. Specimens of what I take to be this species are in the Atkinson Herbarium, with complete notes on the fresh plants. There seems to be a viscidity on the stem, which Murrill overlooked. The spores are rather variable in size. The stem is solid and the plants are large, characters which would separate the species from the "spumosa" group. It may grow in subcespitose clusters as well as solitary. The Ithaca plants grew on dead willow trunks.

Flammula lenta Fr. The exact limitations of this frequent European species are not quite clear. Following Quélet, Rea (20) excludes it from Flammula, making it a synonym of Hebeloma glutinosa Fr., but this point of view is strongly objected to by Ricken (2I). Murrill includes it as an American species, and considers $F$. betulina $\mathrm{Pk}$. a synonym. We have an American plant which agrees entirely with the account of Fries (6); it has slender and toughish stems, and its spores measure $5^{-6.5} \times 3-4 \mu$. The gills are at first white, later greenish-ochraceous, and finally clay color with a slight incarnate-subpurplish tint; the spores, however, are very pale under the microscope, tinted smoky-ochraceous. It grows on much-decayed wood remnants and débris in coniferous forests. F. betulina $\mathrm{Pk}$. has both a different habitat and habit; it occurs on logs of white birch and is usually a much stouter and more compact plant. Its spores are distinctly wider and subreniform. In both the pileus is pale grayish-buff and decorated with white veil remnants on the margin. Apparently $F$. betulina is less glutinous in wet weather than $F$. lenta. The cystidia of the two species are very similar, rather stoutly ventricose, with a stout, obtuse, subcylindric neck and a slender pedicel. The odor and taste of both are mild or nearly so.

Flammula liquiritiae Fr. This seems to be rare in this country, or is it perhaps frequently confused with other species? Fries has left the impression in his figures in Icones (Pl. I I9, fig. I) that it is a long-stemmed species; his own descriptions, however $(6,7)$ do not bear this out. The stem is rather slender, but rarely over $5 \mathrm{~cm}$. long. I have it from the Medicine Bow Mountains of Wyoming, on coniferous wood. This collection fitted well into the description given by Ricken, except that the sterile cells on the edges of the gills ("cystidia" as called here by Ricken) are filiform, capitate, and hyaline, measuring $35^{-40} \mu$ in length, both on the sides and on the edges of the gills. The gills are broadly adnate-subdecurrent and 6-8 $\mathrm{mm}$. or more in width. It is known, in addition, by the absence of a cortina, by the glabrous cap and stem, and by the orange-fulvous pileus. Murrill (I4) does not mention it.

Flammula lubrica Fr. This European species is omitted by Murrill 
(14). However, we have in this country a species so close to the descriptions of Fries, and so well illustrated by his figures (Icones, P1. I I6, fig. I) that it is doubtless the same. Microscopically it differs from Ricken's conception of that species by the slightly longer spores. The only other species it might be referred to is $F$. subfulva $\mathrm{Pk}$., but I have been unable to distinguish clearly between these two, further than Peck himself did. I have collected the species mentioned above as $F$. lubrica, in the Adirondack Mountains, as well as in the mountains of Colorado and Washington. The pileus is "ochraceous-orange" to "zinc-orange" (Ridg.) and tawny on the disk. The cortina is usually well developed, leaving remnants on the margin of the pileus and a cortinate, evanescent zone at the apex of the fibrillose stem. The cystidia are rather characteristic, 50-65(70) $\times 10-15 \mu$ in size, thick-walled in mature plants, and many of them with a somewhat irregular

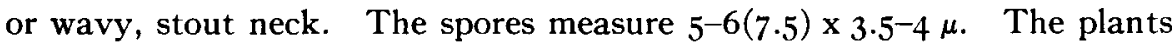
are usually larger than most Flammulae.

My notes show that there is a radish-like odor present in greater or less degree; sometimes the odor is slight, at other times strong and penetrating. All these collections grew on or about coniferous logs or débris. Fries does not emphasize its habitat in connection with conifers. Nor is it possible with all these data to draw a line, with reference either to the odor or to the wood relations, between $F$. lubrica and $F$. subfulva. The latter, apparently, is a smaller plant, but the type collection is not sufficient to establish this point. This species, by its pale gills and spores, verges towards the genus Hebeloma, and when not attached to wood, as sometimes happens, might well be looked for in that genus.

Flammula magna Pk. This and Cortinarius validipes Pk. are undoubtedly identical. Only mature or overmature plants were studied by Peck. and the species needs further attention when fresh young stages are found, The type plants of both look like large rusty-yellow Cortinarii, but the gills are truly decurrent and narrow. The veil characters if any are entirely unknown, but a veil of some sort is indicated by the fibrillose stems. The spores are exactly the same in both collections, broadly ellipsoid, minutely tuberculate, rusty-yellow under the microscope, and measure (8) 9-10 x 5$6 \mu$. Cystidia are lacking.

Flammula mixta Fr. The plants collected by me at North Elba, Adirondack Mountains (Io), and referred to this species, are something else. The species is so far unknown in this country.

Flammula malicola nov. nom. This is $F$. sulphurea $\mathrm{Pk}$. (non Massee). Murrill has made $F$. sulphurea a synonym of $F$. alnicola. There are many similarities in the dried herbarium specimens of the two, but I believe that Peck rightly kept it separate. His reasons are given in his comments (N. Y. State Mus. Bull. 157: 26. 1912), viz.: "from $F$. alnicola" it differs "by its place of growth, white flesh, and viscid, hygrophanous pileus." He might have added that it is also more markedly umbonate and brighter in color; 
the gills are narrower, and the spores slightly larger than in $F$. alnicola. When dried the viscid surface of the pileus has become markedly rugosewrinkled, and the umbo prominent. Its "odor and taste is disagreeable" (Peck). F. alnicola marginalis $\mathrm{Pk}$. appears to be a form of the same species.

Flammula multifolia Pk. The spores were said by Peck to be subglobose, $4^{-5} \mu$ in diameter. They are, however, oval to elliptic-oval, measuring $6-7.5 \times 3.5^{-5} .5 \mu$, and are rounded at one end; some of them resemble corn kernels in shape. F. expansa Pk. is the same.

Flammula ochrochlora Fr. This species seems hitherto to have been unknown in the United States. Specimens from Sweden in the Atkinson Herbarium agree closely with the account given by Rea (20), especially in their microscopic characters. The gills of the dried Swedish specimens are "tawny olive" to "snuff brown" (Ridg.). Material which I collected in the Adirondack Mountains is very probably this species, although the dried gills are somewhat darker.

Flammula penetrans Fr. Murrill has placed here what I consider, in part at least, to be the Friesian species $F$. sapinea. F. penetrans has a glabrous, not a floccose-scaly pileus, and the colors are different. Material from Romell, in the Atkinson Herbarium, is without doubt the Friesian species. The spore characters given by Ricken (2I) and Rea (20) are obviously not from their own studies but copied from Saccardo, and the size quoted is 8-9 $\times 4-5 \mu$. This is also the spore size of $F$. sapinea. In the Swedish specimens mentioned above, the spores are characteristic in size and shape; they measure $6-7.5 \times 3.5-4.5 \mu$ and tend to be ventricose in shape. The spore sizes as given by Saccardo for the basidiomycetes are well known to be undependable.

Flammula permollis Murrill. The type of this species has spores which are almost hyaline under the microscope, but lying against the gills they show a pale ochraceous color. It is insufficiently described.

Flammula polychroa Berk. For a full account of this see Kauffman (I I, p. 484).

Flammula sapinea Fr. In the older American lists this was nearly always reported, largely because the conifer substratum was supposed to be all-sufficient. Murrill (14) excludes it altogether and in its place gives $F$. penetrans the honor of a common American distribution. In my own field experience I have found no facts to support Murrill's opinion. I still consider F. sapinea Fr. a good American species. Fries' plate (Icones, Pl. I 8 , fig. 3 ), to be sure, shows luxuriant plants, and he speaks of it as a "noble species"; but, although one ordinarily finds only small-sized plants, rarely a few large specimens do appear. Very few species of conifer-loving Flammulae have a scaly pileus, and this one is easily recognizable. Only one or a few scattered plants are ordinarily seen in a place, although they may be cespitose at times. It has a rather strong odor. If I am correct in this diagnosis, then $F$. eccentrica $\mathrm{Pk}$. becomes a synonym. An examination of 
the decayed wood remnants found with the type of $F$. eccentrica showed that it grew on coniferous wood. I have frequently seen $F$. sapinea with both deformed and eccentric stems, especially when growing cespitose. This feature is referred to in a broad way by Fries (6) when he says the stems are "difformis."

Flammula spumosa Fr. This and the closely related species can be called "the spumosa complex." The group consists of $F$. spumosa, F. graveolens, $F$. squalida, $F$. subflavida, and $F$. piceina. When the growing history and constancy of certain characters are fully known, it may be possible to differentiate clearly between these species. At present the dividing lines are vague and many necessary details are not recorded. $F$. graveolens is fairly well differentiated from $F$. spumosa by its odor and slightly different spores, as well as by a number of minor characters; it is probably a segregate of the old European $F$. spumosa. $F$. squalida is not well known. The two species of Murrill need further study before they can be distinguished. Rea (20) gives the spore size too large.

The colors of flesh, cap, and stem are much used in this group, but are very confusing. The parts may be sulfur-yellow, greenish-yellow, dull yellow, etc., but the shades vary with the age of the fresh plants when picked; there is always a tendency towards a fulvous or tawny color on the disk of the pileus, and the stems, especially the lower portion, may be fuscescent, ferruginescent, or brunnescent. Data on a sufficient number of collections, showing just how the gills are attached, their width and spacing, are not at hand. All the collections appear to have a stuffed to hollow tubule in the stems. They all have a manifest cortina; in $F$. spumosa this is regularly pale greenish-yellow according to Fries (6). A complete account of the stages at time of collecting may show that colors and color changes are constant for each form, but for several of the group I have not been able to make such notes.

Flammula squalida Pk. By its subcartilaginous stems, this species verges towards the genus Naucoria; otherwise, however, it belongs to the "spumosa" complex. (See under F. spumosa.)

Flammula subflavida Murrill. This also belongs to the "spumosa" complex; as in the species previously mentioned, the cortina is at first fibrillose-interwoven so as to appear almost membranous. (See F.spumosa.)

Flammula subfulva Pk. Peck points out that this may be only a form of F. lubrica (N. Y. State Mus. Rep. 50: 136). It is said to differ from the latter species in the uniform color of the pileus and the grayish-white flesh. The type has cystidia with slender necks, which are wavy in outline as in $F$. lubrica. It should perhaps be excluded. (See remarks under F. lubrica.)

Flammula subviridis Murrill. This is a very distinct species which I have collected in the Cascade Mountains east of Seattle. The type specimens were sent by Miss McKenny from Olympia, Washington, and were accompanied by three colored drawings, from which the species is readily 
recognizable. It is very different in its habit and characters from Pholiota aeruginosa, having a long tapering or rooting stem, without a cortina even in the young stage. The whole young plant is at first covered by a whitish pulverulence which may be considered as a sort of universal veil, and which at length disappears, especially on the stem. F. picrea Fr. is clothed in the same manner, and these two species are related. Individuals vary in size; sometimes the mature pileus measures only $4-5 \mathrm{~cm}$. while the stem is $5^{-7}$ cm. long; at other times the plants reach the size given by Murrill. The pileus, stem, and gills are "pyrite-yellow" to "warbler green" (Ridg.), but may become deeper-colored in age, the gills at length being stained by the ferruginous spores. The taste is intensely bitter; the odor, none. $F$. ochrochlorus Fr. differs by its cortina and somewhat scaly stem, and by its smaller size and paler colors. The spores of the two seem to be alike.

Flammula sulphurea $\mathrm{Pk}$. (See $F$. malicola.)

Flammula unicolor Murrill. The spores of the type specimens measure 7-9 $\times 4-5 \mu$ (not Io $\times 6 \mu$ as given by Murrill). The cystidia are abundant.

- Flammula velata $\mathrm{Pk}$. In this species, according to Peck (Bull. Torrey Bot. Club 30:96), "the strongly developed veil is a prominent character of the species." The type specimens came from Idaho. The cystidia are abundant, ventricose-sublanceolate, $50-60 \times 10-{ }^{-13}$ (I5) $\mu$, hyaline, with a slender pedicel; the surface is longitudinally striate, the outline undulate. The spores are broadly elliptical, $6.5^{-7.5(8)} \times 4^{-5} \mu$, and are yellowish under the microscope. "Taste mild."

Flammula vialis Murrill. This western species seems to differ sufficiently from the "spumosa" group by its solid stem, non-cespitose habit, and scattered cystidia. Although the pileus was described as dry, the type specimens indicate that it had at least a subviscid, separable pellicle. The cystidia are mostly found at and near the edges of the gills, are subventricose with a cylindrical neck and slender pedicel, hyaline, and measure about $60-70 \times 10-14 \mu$. The spores are ellipsoid in one view, plano-convex in the other, and measure $6.5^{-7.5} \times 3.5^{-4} \mu$. The specimens grew on a railroad tie which may have been of coniferous wood.

\section{Synonyms and Excluded or Doubtful Species of Flammula}

Species known only from the British Isles: $F$. aldridgei Massee (syn. $F$. veluticeps Cke. \& Massee). F. carnosa Massee. F. clitopila Cke. \& Smith. F. decipiens W. G. Smith. F. flicea Cke. F. floccifera B.\& Br. F. inaurata W. G. Smith. F. juncina W. G. Smith. F. nitens Cke. \& Massee. F. purpurata Cke. \& Massee.

Gymnopilus Abramsii Murrill = Cortinarius sp.

F. aliena $\mathrm{Pk} .=$ Paxillus sp., probably P. scambus (Fr.) Quél.

F. anomala $\mathrm{Pk}$. = Paxillus anomala (Pk.) comb. nov.

F. apicrea Fr. Not known at present.

Gymnopilus aromaticus Murrill $=$ Pholiota sp., probably a form of $P$. muricata Fr. 
F. ascophora $\mathrm{Pk} .=$ Flammula highlandensis $\mathrm{Pk}$.

$F$. austera Fr. Not known at present.

Gymnopilus autumnalis ( $\mathrm{Pk}$.) Murrill (=Agaricus autumnalis $\mathrm{Pk}$. N. Y. State Mus. Rep. 23: 92. 1873). Peck changed the name to Pholiota autumnalis in 1908. Murrill (14), in his account of the Flammulas, gives it the name mentioned above. Overholts (I5), finally, makes it a synonym of Pholiota marginata. In the N. Y. State Mus. Bull. 157: 9. I9I2, Peck reports a fatal case of poisoning from eating what was supposedly this mushroom. Mary Whetstone, M.D., of Minneapolis, Minn., who sent the data quoted by Peck, has several times kindly sent me collections of this noxious form from the original locus. The spores of this harmful species are too narrow and the gills are too broad for it to be considered P. marginata. The taste is bitter, becoming disagreeable in the mouth; it is quite strong and nauseous. The cortina is not very marked, although the stem is cortinate-fibrillose. The plants grew on rotten sticks and débris in a lumber yard. This western species is therefore probably undescribed, but until my notes on the fresh plants are fuller it is better to leave it without a name. A fuller account of its poisonous qualities has appeared (Kauffman, II, p. 854).

Gymnopilus bellulus (Pk.) Murrill = Naucoria bellula (Pk.) Sacc.

F. bresadolae Schulz. Unknown in America.

F. californica Earle. Probably a Hebeloma.

$F$. decurrens $\mathrm{Pk}$. The type was not seen and is probably not in existence. It is omitted by Murrill (I4).

$F$. decussata Fr. Not known at present.

F. echinulispora Murrill $=$ Cortinarius $\mathrm{sp}$.

F. eccentrica $\mathrm{Pk} .=$ Flammula sapinea $\mathrm{Fr}$.

F. edulis $\mathrm{Pk}$. = Hebeloma edule ( $\mathrm{Pk}$.) comb. nov.

F. expansa $\mathrm{Pk} .=$ Flammula multifolia $\mathrm{Pk}$.

Gymnopilus fagicola Murrill = Pholiota fagicola (Murrill) comb. nov.

F. farinacea Murrill = Cortinarius farinaceus (Murrill) comb. nov.

F. filia Fr. Not much known about this species.

Gymnopilus foedatus (Pk.) Murrill. This was described by Peck as a Hebeloma. It should be Cortinarius foedatus (Pk.) comb. nov.

Gymnopilus geminellus (Pk.) Murrill = Naucoria geminella (Pk.) Sacc.

F. granulosa $\mathrm{Pk} .=$ Pholiota muricata Fr.

F. helomorpha $\mathrm{Fr} .=$ Paxillus helomorphus $(\mathrm{Fr}$.$) Quél.$

F. hillii Murrill = Naucoria bellula (Pk.) Sacc.

F. laeticolor Murrill = Flammula astragalina $\mathrm{Fr}$.

$F$. lenta Fr. = IIebeloma glutinosum Fr.

Gymnopilus longisporus Murrill = Paxillus longisporus (Murrill) comb. nov.

Gymnopilus oregonensis Murrill = Naucoria oregonensis $\quad$ (Murrill) comb. nov. 
F. pallida Murrill. Probably a Hebeloma.

F. praecox $\mathrm{Pk} .=$ Cortinarius praecox $(\mathrm{Pk}$.) comb. nov.

F. pulchrifolia $\mathrm{Pk} .=$ Flammula braendlei $\mathrm{Pk}$.

F. pusilla $\mathrm{Pk} .=$ Flammula highlandensis $\mathrm{Pk}$.

F. rubicunda Rea. Why not a Cortinarius?

F. scamba Fr. = Paxillus scambus (Fr.) Quél.

F. sphagnophila $\mathrm{Pk}$. = Tubaria sphagnophila (Pk.) comb. nov.

$F$. spinulifer Murrill $=$ Psilocybe sp. with purple-brown spores.

Gymnopilus squamulosus Murrill = Pholiota squamulosus (Murrill) comb. nov.

F. subcarbonaria Murrill = Cortinarius sp.

F. tammii Fr. = Phylloporus rhodoxanthus (Schur.) Bres.

F. Tricholoma (A. \& S.) Quél. = Paxillus Tricholoma (A. \& S.) Fr.

F. viridans Fr. = Pholiota aeruginosa $\mathrm{Pk}$.

F. viscida $\mathrm{Pk} .=$ Pholiota viscida $(\mathrm{Pk}$.) comb. nov.

$F$. viscidissima Murrill = Cortinarius sp.

\section{Paxillus}

The natural relationships of the genus Paxillus, as it has come down to us, are such that the species which have been placed in it, or which probably should be placed in it, link the genus on different sides to Clitocybe, Clitopilus, Flammula, Inocybe, and the Boletaceae respectively. What was true when Fries (7, p. 40I) remarked that "the genus is not yet properly defined" remains true today.

The generic characters that stand out in the traditional usage are: $(a)$ the anastomosing gills, a character which shows relationship to the Boletaceae, especially Phylloporus rhodoxanthus (Schw.) Bres. (see Kauffman, Io); (b) the discrete hymenophore and therefore the ease with which it is separable from the trama of the pileus, a character not infrequent in the genus Clitocybe; $(c)$ the decurrent gills common to Clitocybe, Clitopilus, and Flammula; and $(d)$ the color of the spores, which varies over a considerable range, being either almost white or with ochraceous or flesh tints or, in some specimens, yellowish to rusty-colored, thus showing connections with Clitopilus and Flammula.

Fries (7) separated the eccentric and central-stemmed species and placed them in his tribes Tapinia and Lepista respectively. Without going further into the interim history of the group, it will serve my purpose sufficiently to discuss only a few of the recent attempts to handle the species of this group. Rea (20) places all the older species of Paxillus as well as Phylloporus rhodoxanthus in this genus, and includes it in the Boletaceae. This arrangement seems to me to do violence to the essential characters of the families concerned. To my mind, Ricken (2I) has approached the matter in a much more effective way. Here we find what is equivalent to a division of the genus Paxillus into four subgenera; Paxillus Fr., Clitopilus 
Fr., Tapinia Fr., and Ripartites Karsten. However, whatever one does with the old genus Clitopilus, it is quite unlikely that all the even-spored species of that genus which are now known could be made to fit naturally into this grouping under Paxillus. On the other hand, I believe that for the present Ricken's procedure with regard to the other three subgenera is a step in the right direction. It will perhaps give us an understanding of a number of troublesome species-species which have always been outcasts, and whose place in any classification was never assured.

If we attempt now to arrange the better-known species by an approximate use of Ricken's three subgenera, we shall be able to place certain species hitherto ambiguous elsewhere into proper alignment with each other.

The following outline, therefore, is presented as a temporary arrangement of the species;

I. Paxillus proper. Spores elliptical to subf usiform. Gills sinuate-subdecurrent.

$P$. sordarius $\mathrm{Fr}$.

$P$. extenuatus $\mathrm{Fr}$.

$P$. longisporus (Murrill) Kauff.

II. Tapinia. Spores elliptical. Gills decurrent, forked or anastomosing.

$P$. corrugatus Atk.

$P$. panuoides Fr.

$P$, atrotomentosus $\mathrm{Fr}$.

$P$. involutus $\mathrm{Fr}$.

III. Ripartites. Spores globose to subglobose, minutely rough or smooth. Gills adnate to decurrent.

P. Tricholoma (A. \& S.) Fr.

$P$. helomorphus Fr.

$P$. scambus Fr.

$P$. alienus (Pk.) Kauff.

$P$. anomalus (Pk.) Kauff.

\section{Comments on the Species of Paxillus}

Paxillus alienus (Pk.) comb. nov. This is a rare species. It was described originally from Mt. Gretna, Pennsylvania, from specimens growing on partly buried anthracite coal. I collected it in the same locality in I924, growing on humus or wood remains, and, although I have no specimens from elsewhere, I feel sure I have also seen it rarely in other parts of the country. It usually grows solitary, and not necessarily on coal. The pileus is "grayish-olive-buff" (Ridg.), almost subviscid or merely moist when fresh, with decurved margin, $2-4 \mathrm{~cm}$. broad. The gills are decurrent, narrow, and crowded. In Peck's description the gills are said to be "subdistant," but I think this is doubtful. The stem is concolorous and glabrous except at base. The spores, like those of the type specimens at Albany, are globose, minutely echinulate, $3^{-4 \mu}$ in diameter, the size given by Peck being too large. There are no cystidia. This species may be $P$. scambus Fr., but further collections and notes are necessary. $P$. scambus is described as having adnate gills. 
Paxillus anomalus $(\mathrm{Pk}$.) comb. nov. The type specimens of this have globose, smooth spores, 4-6 $\mu$ in diameter. The spores are subhyaline under the microscope, with a slight smoky-ochraceous tint, certainly not "brownish-ferruginous" as given in Peck's description. It is poorly known, but is separable from $P$. alienus by its smooth spores, its umbonate-infundibuliform pileus, and its "cespitose" habit.

Paxillus atrotomentosus Fr. is well known (see manuals).

Paxillus corrugatus Atk. is fully described by its author.

Paxillus extenuatus Fr. This is not with certainty known as occurring in the United States, but I suspect that I have had it on several occasions.

Paxillus helomorphus Fr. Not known in America.

Paxillus involutus Fr. In the coniferous regions of America. Not abundant.

Paxillus longisporus (Murrill) comb. nov. This was described by Murrill (I4, p. 207) as a Flammula. It is well marked by its long, subfusiform spores and by the distinct olive-greenish hue in the dried type specimens. The spores measure longer than the length given by Murrill. They are oblong-fusiform, subhyaline, slightly tinged with ochraceous, $9-12 \times 3.5-4.5 \mu$ in size, and the epispore is slightly and longitudinally wrinkled under the high power of the microscope. Cystidia are present although hard to find; they are not at all of the Flammula type, $70^{-85} \times$ I $^{-}$ I6 $\mu$, hyaline and smooth. By its spores the species seems to be related to Clitopilus orcella, but in other respects it is very different and its position is very probably within this group. Its characters generally bring it close to $P$. sordarius Fr.

Paxillus panuoides Fr. Although infrequently found, I have one collection from nearly every part of the United States visited. It of ten grows in dark places, caverns, on coal-mine timbers, and in similar situations, although not exclusively so.

Paxillus scambus Fr. Not definitely known in America. (See remarks on $P$. alienus (Pk.).)

Paxillus sordarius Fr.-Ricken. I have what I interpret as this species from the Adirondack Mountains and from Colorado. The spores are narrow, subelliptic, pointed at one end, almost subfusiform, hyaline, 8-9(10) $\times 3.5 \mu$. There are no cystidia present. The gills are easily separable from the hymenophore; they are soon "avellaneous" to "woodbrown" (Ridg.), at first obtusely adnate, becoming sinuate-decurrent, crowded and moderately broad, almost narrow at times. The pileus is $5^{-8} \mathrm{~cm}$. broad, varying in color from "pinkish buff" to "cinnamon buff," becoming sordid, and, like the flesh, mottled with watery streaks. The stem is rather stout, 5-6 cm. long, 7-10(12) $\mathrm{mm}$. thick, of ten clavateenlarged below or abruptly short-pointed at the very base, spongy-stuffed, concolor, becoming sordid-streaked. Odor and taste slight, sometimes subaromatic and subnauseous. Solitary or subcespitose, on the ground, 
especially on banks along mountain roads, probably mostly from decayed wood remnants in the soil.

Paxillus strigosus Pk. and Paxillus strigiceps Fr. appear to be $P$. Tricholoma.

Paxillus Tricholoma (A. \& S.) Fr. This species has been placed both in Flammula and in Inocybe. It was not originally described under the old genus Agaricus. Its subglobose, minutely echinulate spores are a pale ochraceous color and measure $4 \times 3 \mu$. There are no cystidia. The pileus is noted for its strigose-ciliate margin, which is $2-4 \mathrm{~cm}$. broad; stems are 2-4 cm. lang $\times 3-6 \mathrm{~mm}$. thick, usually smaller rather than the full size given here.

Cryptogamic Laboratory, DEPARTMENT OF BOTANY, UNIVERSITY OF MiCHIGAN

\section{LITERATURE CITED}

I. Bresadola, G. Fungi Tridentini, vols. I, 2. I88I-I900.

2. Buller, A. H. R. Researches on fungi $1: 6$. 1909.

3. - Rea's "British basidiomycetae." Nature 3:213-214. I923.

4. Fayod, V. M. Prodrome d'une histoire naturelle des Agaricinées. Ann. Sci. Nat. Bot. VII, 9: I8I-4II. I889.

5. Fries, E. M. Systema Mycologica I: 250. I 821 .

6. —. Monographia I: 348 . 1857 .

7. - Hymenomycetes Europaei, p. 244. 1874.

8. Hennings, P. Engler and Prantl's "Natürliche Pflanzenfamilien" $\mathbf{I}^{1 * *}: 250$. I 898 .

9. Karsten, P. Rysslands, Finlands och den Skandinaviska halfons Hattsvampar. -Forra delen: Skifsvampar. Bidr. Finl. Nat. Folk 32: I-57I. 1879.

Io. Kauffman, C. H. The fungi of North Elba. N. Y. State Mus. Bull. 179: 80-104. 1915.

I1. - Agaricaceae of Michigan I: 483-492. I918.

12. - The mycological flora of the higher Rockies of Colorado. Papers Mich. Acad. Sci. Arts. Lett. I: IOI-I 50. 192 I.

I3. - Inocybe. North American Flora 10: 227-260. 1924.

14. Murrill, W. A. Gymnopilus. North American Flora 10: 193-215. 1917.

15. Overholts, L. O. Pholiota. North American Flora 10: 261-276. 1924.

16. Patouillard, N. Les Hyménomycètes d'Europe. I 887.

17. - Essai taxonomique sur les familles et les genres des Hyménomycètes. I-184. 1900.

18. Persoon, C. H. Synopsis methodica fungorum. Syn. Fung. 1801 .

19. Quélet, L. Les champignons du Jura et des Vosges I: I-320. I872.

20. Rea, C. British basidiomycetes. 313-324. 1922.

21. Ricken, A. Blätterpilze Deutschlands 1: 202-209. 1914.

22. Saccardo, P. A. Sylloge fungorum 5: 809. 1887 .

23. Smith, W. G. M. C. Cooke's "Handbook of British fungi" I: I20. 187 I. 